Rino Bandlitz Johansen, Commander senior grade and $\mathrm{PhD}$, Researcher and subject matter expert in operational leadership, Norwegian Defence University College;

rinoban@hotmail.com

Monica Martinussen, Professor and research manager, RKBU-North, Faculty of Health

Sciences, University of Tromsø, and the Norwegian Defence University College,

monica.martinussen@uit.no

Nils Kvilvang, $\mathrm{PhD}$ candidate, Hedmark University College, Norway;

nils.kvilvang@hihm.no

\title{
THE INFLUENCE OF MILITARY IDENTITY ON WORK ENGAGEMENT AND BURNOUT IN THE NORWEGIAN ARMY RAPID REACTION FORCE
}

\section{Key words}

Military identity, professionalism, individualism, military performance, engagement, burnout

\begin{abstract}
The present study examined the influence of military identity on work engagement and burnout among members in the Norwegian Army Rapid Reaction Forces (RRF).

Hierarchical regression analyses found work engagement to be predicted by military identity (positively so by professionalism, and negatively by individualism), with individualism also predicting burnout. This is the first study to examine the unique influence of military identity on burnout and engagement among operational army personnel in the Norwegian Armed Forces.
\end{abstract}

\section{Background}

Societal trends over the last 20-30 years have caused radical changes in the application of military power, affecting roles, tasks, service patterns, and skill requirements (Birkinshaw \& Gibson, 2004; Moskos et al., 2000). Military personnel concurrently came to view their occupation differently, which may affect the formation, development and maintenance of military identity (Moskos et al., 2000). At the same time, individual rights seem to have gained importance at the cost of obligations, at odds with the collective nature of the Armed Forces (Franke, 2001). With choice apparently substituted for duty as a basis for selfunderstanding, identity formation has become more difficult (Côté \& Levine, 2002). Accordingly, stress related to role adaption may occur, or performance may be negatively affected by a disrupted self-verification process (Burke, 1991; Burke \& Harrod, 2005).

Social changes and altered operational concepts have thus set the premises for military identity changes, which may positively influence both individual coping and performance, potentially leading to increased levels of operational readiness. Soldiers might also come to 
possess multiple identities, although not necessarily the officially preferred one. This might in turn influence soldiers' stress levels and thus their individual coping and performance (Mylle, 2007).

The last 10 years, attempts have been made on a national level to adjust military identity away from idealism towards professionalism. This move is referred to as the Norwegian military paradigm shift (Eriksson, 2004), and is motivated by the assumption that professionalism is a necessary premise for increased performance. However, research on the relationship between military identity, individual coping and performance appears scarce (Grojean \& Thomas, 2006). Bartone et al. (2002) has also recommended military experience and identity to be investigated as possible predictors of performance in future research.

At a national level, Johansen et al. (2013) found a relationship between military identity and areas of individual performance. In their study of officer cadets at the war academies, they found that professionalism positively predicted perceived military competence and skills, and that individualism negatively predicted organizational commitment. Further, in their study of junior offices candidates, they also found that professionalism positively explained overall military performance. However, this research needs to be developed further to obtain more scientific knowledge. The predictive value of military identity should thus be further examined before new selection and training procedures are adopted for the development of future military leaders. Our approach will hence be based on a similar design as in those two studies mentioned, but within a different context and population, using an extended set of outcome variables. The objective of the present study was to examine possible relationship between military identity and health related outcomes, such as burnout and engagement, among operational soldiers participating in international operations.

\section{Military identity - concept, theories and development}

The broad concept of military identity is rooted in military sociology, and may be explored in normative terms such as culture, attitudes, values, and motivation, often following the classical theoretical paths of Huntington (1957), Janowitz (1960), and Moskos (1977). Military identity and its relationship to performance may also be explored by Social Identity Theory (SIT) (Tajfel \& Turner, 1979). SIT is an empirically based context dependant theory and represents the relationship between the self and the context. Haslam (2004) describes social identification as an internalizing of the values and goals of an organization. Thus, Military identity is closely tied to the Armed forces' prevailing goals, values and tasks, representing the degree to which soldiers and officers are motivated and willing to internalize these. SIT, along with Social Categorisation Theory, also suggests that people categorize themselves as members of certain social groups at different abstraction levels, or as unique individuals. Related to the Armed Forces and military identity, an individual may identify with his or her own career (personal level), at different sub groups within the organization (e.g., Navy, Army), or at the Armed Forces as a whole (e.g., soldier, officer) (Wagner et al., 2005). Such a perspective offers shift of identity depending on which identity that appears most salient. Frequently shifts in type of service and roles, which is quite common in military service, could therefore be expected to affect or cause "changes" in the members` identity, 
and subsequently affect the individuals in certain ways as motivation and performance. Research also indicates that role or identity ambiguity may cause different reactions as mental strain or stress for the individual. Burke and Stets (2009) refer to this as "Type II disruption", where the identity process is exposed to interference from other identities, or "Type IV disruption", where multiple identities are activated at different times or contexts. With changes in both society and the Armed forces offering an extended number of identity choices, military identity is then likely to adjust accordingly among the members, and in turn affect different aspects of performance.

\section{The development and dynamics of Norwegian military identity}

\section{Idealism}

During the cold war, Norway held a key geopolitical role in the terror balance and strategic interplay between NATO and the Warsaw Pact. A Nation in Arms Model was cultivated based on the need for a comprehensive territorial defence. Theoretically, the notion of idealism closely resembles institutional military values as collectivism, patriotism, and altruism (Ulriksen, 2002). Such values have been characterized as necessary conditions for the development and maintenance for the military organisation. This coincided with the institutional values outlined in Moskos ' (1977) well established I-O thesis, where an idealistic identity involves negative attitudes towards participation in international operations, and an emphasis on cause as the primary motivation to serve.

\section{Professionalism}

The end of the Cold War shifted NATO's strategic focus, reduced Norway's geo political importance, and changed the ideal role of the soldier (Janowitz, 1960). Idealism was replaced by Professionalism, an identity expressing an expectation in the Norwegian Armed Forces of (a) the necessity and willingness to participate in international joint operations (expeditionary ethos), (b) a strong instrumental focus, with emphasis on the conduct of operations and combat skills (operational ethos), and (c) team cohesion and war comrade fellowship (peer ethos) (Huntington, 1957; Stensønes, 2012; Wong \& Johnsen, 2011). These elements are also recognized in the Norwegian Joint Military Doctrine (FFOD, 2007). Thus, professionalism could be regarded as the preferred identity in the Norwegian armed forces, and should in terms of SIT represent a set of preferred values, goals and tasks of the organization. Developing and sustaining professionalism could therefore be expected to have a positive impact on individual performance, which is also found by Johansen (2013).

\section{Individualism}

Concurrently, a societal rise of individualism and self-interest has weakened the authority and collective values of the national state. Moskos (1977) argued that the shift of military service from being a calling of vocation to a regular occupation might potentially have a negative impact on the organization. As the Armed forces are collective by nature, the Norwegian joint doctrine also highlights the importance of avoiding egocentricism and selfishness, explicitly 
referring to individualism as a threat to the individual quality of service. In light of SIT, an identity which builds on a variation of individualistic occupational attitudes and motives thus appears to be in conflict with the structure, tasks, and demands of military service. If the discrepancy between service demands and individual self-interest and commitment to service would exceed a certain level, a negative impact on individual on individual performance could be expected. The impact of Individualism has also been tested empirically, indicating negative effects as reduced combat effectiveness (Faris, 1995; Griffith, 2008), and on organizational commitment (Johansen, 2013).

\section{Military identity in relation to work engagement and burnout}

Grounded in SIT, Haslam (2004) argues that social identification plays a key role in establishing important organizational behaviors such as compliance, extra-role proorganizational behavior, loyalty, improved performance, reduced absenteeism and higher levels of physical and emotional well-being. All these elements appear fundamental to the functioning of the Armed Forces, thus linking military identity to both SIT and actual coping and performance. Van Dick et al. (2005) also summarized that identification plays an important role in work-related attitudes and behavior, and that the emotional component of identification is probably the best predictor of performance. Further he argues that the main prediction of SIT for organizational contexts is that the more an individual define him- or herself in terms of membership in an organizational group (as for instance the Armed Forces) the more his or her attitudes and behaviours are governed by this group membership.

Consequently, adapting professionalism should lead to a higher correspondence between preferred and actual identity, thus reducing role ambiguity and role conflict (Haslam, 2004). Furthermore it should also lead to a higher degree of identity verification (Van Dick et al, 2005). These conditions could then act as catalyst for increased individual dedication and vigour, leading to a higher level of work engagement (Gonzalez-Roma et al., 2006). Britt and Bliese (2003) found that in environments where job demands are high, for instance during operations, soldiers with a higher degree of work engagement also reported less elevation of psychological distress.

On the other side, adapting individualism could increase role ambiguity and role conflict as well as reduce the level of identity verification. This in turn could reduce the level of work engagement as well as increase the level of individual psychological distress, potentially leading to burnout.

\section{The present study}

The present study examined the influence of military identity on work engagement and burnout among members of the Norwegian Army RRF (Rapid Reaction Forces). Work engagement and burnout were used as outcomes, since they are related to individual health and well-being as well as work performance, commitment and turnover intentions (Lee \& Ashforth, 1996; Halbesleben, 2010). Further, given their working definition, the constructs of work engagement and burnout, and their underlying dimensions, are highly relevant in military operational environments (Van Boxmeer et al., 2007) 
With Professionalism representing the normative identity of the Norwegian Armed forces, adopting this identity would be expected to have positive consequences. A higher degree of Professionalism should thus be related to less burnout and higher levels of engagement. A higher level of Individualism could however be regarded as a deviation from the identity norm, which might be related to more burnout or a lower level of work engagement.

The two following hypotheses will be tested:

- H1. Professionalism will be positively related to work engagement, and negatively related to burnout.

- $\quad$ H2. Individualism will be negatively related to work engagement, and positively related to burnout.

\section{Methods}

\section{Participants}

A total of 211 candidates participated in the study, with $95 \%$ being male. Participants consisted of army personnel from the RRF unit, dedicated to participation in international operations. The RRF unit consists of professional soldiers recruited and selected from personnel having served their conscription services. They are in general more rigorously selected, better trained and equipped than units consisting of conscripts. The RRF unit has over the years gained considerable experience being deployed to international missions, and the unit, as well as the individual soldiers, must be expected to be more resilient towards combat related stress than other soldiers in regular army units.

The average age of participants was 26 years $(S D=5.2)$. Questionnaires were distributed to all the participants $(N=212)$ and 211 questionnaires were completed resulting in a response rate close to $100 \%$. The study was approved by the Norwegian Social Sciences Data Services.

\section{Measures}

Demographics: Sex and previous international experience (yes/no) (INTOPS) were assessed.

Predictors: Military identity. Military identity was measured by the 33-Item Military Identity Scale (NPIS) (Johansen et al., 2013), which comprises three dimensions; Professionalism (12 items), Individualism (10 items), and Idealism (11 items). All scales where rated on a 7-point Likert scale ranging from 'strongly disagree' to 'strongly agree'. Cronbach's alpha values are displayed in Table 1. Examples of items is; Professionalism: "The possibility of participating in war actions is an important motivating factor to me", Idealism: "I look upon work in the Armed Forces as a calling where I can serve my country", Individualism: "I see being in the Armed Forces as an ordinary job". 
Outcome variables: Work engagement and burnout: Work engagement and burnout were measured by "The Netherlands` Armed Forces Morale Survey Scale" (van Boxmeer et al., 2008). Work engagement was assessed by combining the two subscales of Willingness to Contribute and Energy ( $4+4$ items). Further, Burnout was assessed by combining the two subscales of Exhaustion and Cynicism (4+4 items). All scales where rated on a 7-point Likert scale ranging from 'strongly disagree' to 'strongly agree'. Cronbach's alpha values are displayed in Table 1. Examples of items is; Work engagement: "I am enthusiastic about my job","Burnout: "I am not sure about the purpose of my work".

\section{Procedure and statistical analyses}

Descriptive statistics and intercorrelations were computed for all study variables. Correlations and regression analyses were computed using list-wise deletion of missing data, and Cronbach's alpha was used to estimate internal consistency for the scales included in the study. Separate hierarchical regression models were computed for each dependent variable (Work engagement and Burnout). The first step in each regression model introduced sex and INTOPS as control variables. For the next and final step, the Military identity dimensions were entered to test for any unique influence of these on Work engagement and Burnout. Individual predictors were only interpreted if the corresponding step was significant.

\section{Results}

Descriptive statistics, including correlations between the studied variables, are presented in Table 1. Hypotheses 1, 2 were initially tested by examining correlations. Professionalism was significantly correlated with Work engagement $\left(r=.32^{* *}\right)$ but unrelated to burnout. Individualism was negatively correlated with Work engagement $\left(r=-.20^{* *}\right)$, and positively and significantly correlated with Burnout $\left(r=-.24^{* *}\right)$. Idealism did not correlate with either of the outcome variables. Results of the two subsequently performed hierarchical regression analyses are presented in Table 2 .

Work engagement: When combined, the demographic variables (Sex and INTOPS), failed to explain a significant part of the variance in Work engagement. Military identity, entered in step 2, did however explain a significant part of the variance (16\%) in Work engagement. Of the individual predictors, Professionalism was significantly and positively associated with Work engagement. Individualism also explained a significant part of the variance and was inversely related to Work engagement.

Burnout: Again, the demographic variables (Sex and INTOPS), entered in the first step as control variables, explained a small but significant part of the variance (3.3\%). As an individual predictor, INTOPS experience explained a significant part of the variance, with participation in INTOPS associated with higher degrees of Burnout. The contribution of Military identity in step 2 was also significant (6.4\%). The individual predictor of Individualism explained a significant part of the variance, and was positively related to Burnout. 
Table 1: Descriptive Statistics for Variables in the Study $(\mathrm{N}=211)$

Alpha $\quad M \quad S D \quad$ Sex $\quad$ INTOPS (1) $\quad$ (2) $\quad$ (3) $\quad$ (4) $\quad$ (5)

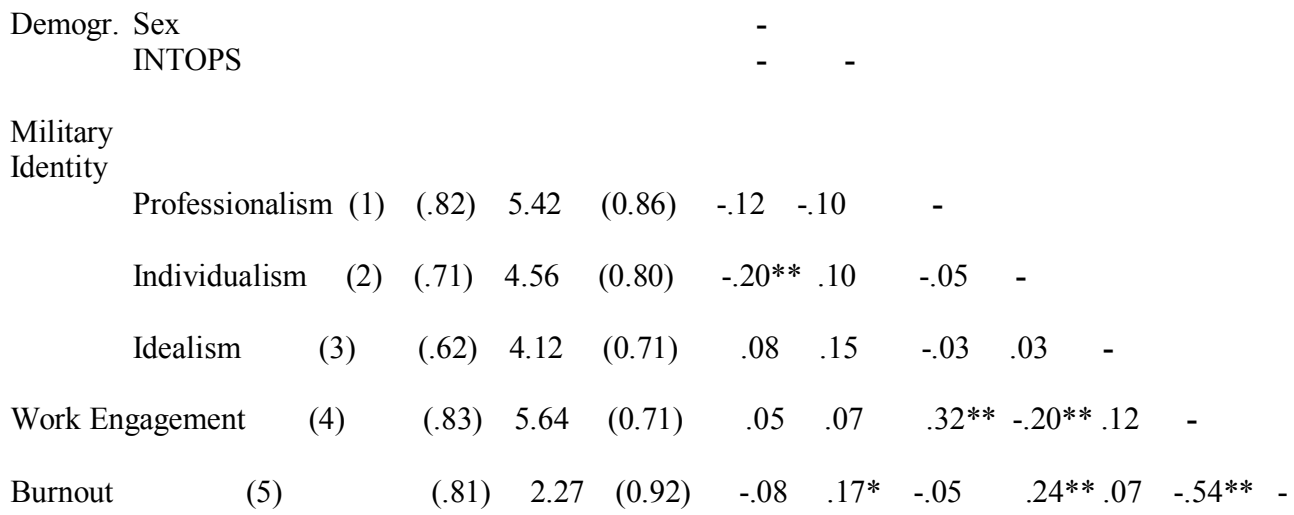

Note. ${ }^{*} p<.05 .{ }^{* *} p<.01$ (two-tailed). Sex was coded $0=$ male and $1=$ female. Previous military experience was coded $0=$ no previous INTOPS experience, $1=$ previous INTOPS experience.

Table 2: Hierarchical Multiple Regression Analysis for Predicting Engagement and Burnout

\begin{tabular}{|c|c|c|c|c|}
\hline \multirow[b]{2}{*}{ Variables } & \multicolumn{2}{|c|}{ Engagement } & \multicolumn{2}{|c|}{ Burnout } \\
\hline & $\beta$ & $\Delta R^{2}$ & $\beta$ & $\Delta R^{2}$ \\
\hline Step 1. Demographics & & .007 & & $.033^{*}$ \\
\hline $\begin{array}{l}\text { Sex }^{\mathrm{a}} \\
\text { INTOPS }^{\mathrm{b}}\end{array}$ & $\begin{array}{c}0.04 \\
0.10\end{array}$ & & $\begin{array}{r}-0.14^{* *} \\
0.16^{* *}\end{array}$ & \\
\hline Step 2. Military identity & & $.160 * * *$ & & $.064 * * *$ \\
\hline $\begin{array}{l}\text { Professionalism } \\
\text { Individualism } \\
\text { Idealism }\end{array}$ & $\begin{array}{l}0.33^{* * *} \\
-0.19^{* *} \\
0.12\end{array}$ & & $\begin{array}{l}-0.05 \\
0.25 * * * \\
-0.05\end{array}$ & \\
\hline $\begin{array}{l}R^{2} \\
N\end{array}$ & & $\begin{array}{l}.167 * * * \\
211\end{array}$ & & $\begin{array}{l}.097 * * * \\
211\end{array}$ \\
\hline
\end{tabular}

Note: All coefficients were taken from the last step of the regression analysis. ${ }^{*} p<.05,{ }^{* *} p<.01$, $* * * p<.001$.

${ }^{\mathrm{a}} \mathrm{Sex}$ was coded $0=$ male and $1=$ female. Previous ${ }^{\mathrm{b}}$ INTOPS experience is defined as having participated in at least one international operation.

\section{Discussion}

The purpose of this study was to examine whether military identity predicts work engagement and burnout. Sex and INTOPS were included as control variables.

We found moderate positive correlations between professionalism and work engagement. Individualism showed a moderate negative correlation with work engagement, while being positively related to burnout. Our findings thus supported both Hypothesis 1 and 2. 
According to our regression analyses, demographic variables predicted only a small amount of the variance in burnout. Sex had a significant effect on burnout, with males scoring slightly higher than females. However, as the number of females in this sample appeared as very small (11) compared to the number of males (200) this finding is not elaborated further.

The regression analysis in our study showed that INTOPS predicted burnout, indicating that respondents who had participated in at least one international operation scored slightly higher than those lacking similar experience. This finding might be expected due to the stress and strain inevitably experienced by personnel participating in international combat operations. However, with combat operations constituting the core of military service, this association should be regarded as a matter for concern, and investigated further. This is especially important for personnel who are frequently deployed on international missions. Future studies should explore in greater detail the stressors associated with being deployed including increased family role conflicts, and its`impacts on burnout and other outcomes such as mental health including PTSD.

Finally, the step involving military identity added significantly to the prediction of both work engagement (16\%) and burnout $(6.4 \%)$. The individual predictor of professionalism had a significant positive effect on work engagement, indicating that identifying more closely with professionalism, as encouraged by the official doctrine, is associated with a higher degree of work engagement in respondents. This positive relationship between professionalism and work engagement among members in the RRF is encouraging, and supports Hypothesis 1 as to the expected positive outcome of professionalism. It also supports previous research conducted by Johansen et al. (2013), whofound professionalism to predict individual performance including overall scholastic achievement, military skills and commitment among Norwegian junior officer students. It further corresponds to the findings of Britt (2003), whom in his study of 1200 US Army Rangers found that high levels of warriorism were positively related to levels of work engagement during missions where job guidelines were unclear. With Britt's chosen warriorism scale sharing several items with the professionalism scale used in our current study, these findings appear to tap into similar constructs.

Our findings that individualism appears negatively related to work engagement, and positively related to burnout lend support to Hypothesis 2, and also to previous research indicating that individualistic identity might negatively affect in-combat efficiency (Faris, 95; Griffith, 2008). The present findings also support the assumption that individualism might be difficult to reconcile with productive and sound military service at an individual level.

\section{Study strengths and limitations}

The strength of the study is how it represents a unique step towards greater insight into the interplay between military sociological and psychological phenomena. Further, the study is also one of few to involve the measurement of work engagement and burnout in military operational personnel. One limitation of this study is its cross sectional design, which means that no firm conclusions can be drawn as to causality. The study also relies solely on self- 
reports which may increase common method variance (CMV) (Lindell \& Whitney, 2001). On the other hand, Adler and Thomas (2005) compared self-reports with unit records among US soldiers, and found satisfactory concordance between self-reports and unit records along performance domains as demonstration of effort, which to some degree are comparable to the measures employed in this study.

\section{Conclusions and practical implications}

Building on Johansen's (2013) two studies, our findings confirm professionalism to be advantageous and individualism to be disadvantageous. As it also present new insight into the interplay between military sociological and psychological phenomena, the findings may also contribute to theoretical and practical developments. The study also reveals that individualism appears negatively related to work engagement, and positively related to burnout. This could indicate that an individualistic identity might negatively affect in-combat efficiency. However, proposing practical implications based on these finding must be done with caution.

The findings may though contribute to improvement of educational, developmental as well as character building programs. Future studies should be conducted to further explore and evaluate the potential impact of different aspects of military identity, not only how it relates to performance and coping variables, but also how it develops over time.

\section{References}

Adler, A. B., Thomas, J. L., \& Castro, C. A. (2005). Measuring up: Comparing self-reports with unit records for assessing soldier performance. Military Psychology, 17, 3-24.

Bartone, P. T., Snook, S. A., \& Tremble, T. R. (2002). Cognitive and personality predictors of leader performance in West Point cadets. Military Psychology, 14, 321-338. doi: 10.1207/S15327876MP1404_6

Birkinshaw, J., \& Gibson, C. (2004). Building ambidexterity into an organization. Harvard Business Review, Summer, 47-55.

Britt, T. W. (2003). Aspects of identity predict engagement in work under adverse conditions. Self and Identity, 2, 31-45. doi: 10.1080/15298860309022

Britt, T, W., \& Bliese, P. D. (2003). Testing the stress-buffering effects of self engagement among soldiers on a military operation. Journal of Personality, 71, 245-266.

Burke, P. J., \& Stets, J. E. (2009). Identity theory. Oxford: Oxford University Press.

Burke, P. J. (1991). Identity Processes and social stress. American Sociological Review, 56, 836-849. doi: $10.2307 / 2096260$

Burke, P. J., \& Harrod, M. M. (2005). Too much of a good thing? Social Psychology Quarterly, 68, 359-374. doi: 10.1177/019027250506800404

Côté, J. E., \& Levine, C. G. (2002). Identity formation, agency, and culture: A social psychological synthesis. Mahwah, NJ: Lawrence Erlbaum Associates.

Eriksson, M. (2004). Idealism eller professionalism? [Idealism or professionalism?]. PACEM, 7,75-90.

Faris, J. H. (1995). The Looking-glass army: Patriotism in the post-cold world era. Armed Forces and Society, 21, 411-434. doi:10.1177/0095327X9502100306

Forsvarsstaben. (2007). Forsvarets Fellesoperative Doktrine [Norwegian Armed Forces Joint Military Doctrine]. Oslo: 
Franke, V. C. (2001). Generation X and the military: A comparison of attitudes and values between West Point cadets and college students. Journal of Political and Military Sociology, 29, 92-119.

Griffith, J. (2008). After 9/11, what kind of reserve soldier? Considerations given to emerging demands, organizational orientation, and individual commitment. Armed Forces \& Society, 35, 214-240. doi: 10.1177/0095327X07312490.

González -Romá, V., Schaufeli, W. B., Bakker, A. B,. \& Lloret, S. (2006). Burnout and work engagement: Independent factors or opposite poles? Journal of Vocational Behavior, 68, 165-174. doi:http://dx.doi.org/10.1016/j.jvb.2005.01.003

Grojean, M., W., \& Thomas, J., L. (2006). From values to performance: It`s the journey that changes the traveler. In T. W. Britt, A. B. Adler, \& C. A. Castro (Eds.), The Psychology of serving in peace and combat: Military Culture (pp. 35-59). London: Praeger Security International.

Halbesleben, J. R. B. (20109. A meta-analysis of work engagement: Relationships with burnout, demands, resources, and consequences. In A. B. Bakker \& M. P. Leiter (Eds.), Work engagement: A handbook of essential theory and research (pp. 102-117). New York: Psychology Press.

Haslam, S. A. (2004). Psychology in organizations. Chippenham: CPI Antony Rowe.

Huntington, S. P. (1957). The soldier and the State. London: The Belknap Press of Harvard University Press.

Janowitz, M. (1960). The professional soldier - a social and political portrait. New York: Free Press of Glencoe.

Johansen, R. B., Laberg, J. C., \& Martinussen, M. (2013). The impact of military identity on junior officer students. Journal of Political and Military Sociology: An annual review, $42,75-99$.

Johansen, R. B., Laberg, J. C., \& Martinussen, M. (2013). Military identity as predictor of perceived military competence and skills. Armed Forces \& Society, Published online before print May 28, 2013, doi: 10.1177/0095327X13478405

Johansen, R. B., Laberg, J. C., \& Martinussen, M. (2013). Measuring Norwegian military identity: Scale development and psychometric evaluations. Social behavior and Personality, 41, 861 - 880. doi: org/10.2224/sbp.2013.41.4.861

Lee, R., \& Ashforth, B. (1993). A further examination of managerial burnout: Toward an intergated model. Journal of Organizational Behavior, 14, 3-20. doi: 10.1002/job.4030140103

Lindell, M. K., \& Whitney, D. J. (2001). Accounting for common method variance in crosssectional research designs. Journal of Applied Psychology, 86, 114-121. doi: 10.1037//0021-9010.86.1.114.

Moskos, C. (1977). From institution to occupation. Trends in military organization. Armed Forces and Society, 4, 41-50. doi: 10.1177/0095327X7700400103

Moskos, C., Williams, J. A., \& Segal, D. R. (2000). Armed forces after the cold war. In C. Moskos, J. A. Willams, \& D. R. Segal (Eds.), The postmodern military: Armed forces after the cold war (pp. 1-13). New York: Oxford University Press.

Mylle, J. (2007). From a psychological to a behavioural sciences approach and beyond in military research: Current status and trends. In G. Caforio (Ed.), Social Sciences and the Military. An interdisciplinary overview (pp. 123-143). Oxon: Routledge.

Stensønes, M. (2012). På våre vegne [On our behalf]. Oslo: Aschehoug \& Co.

Tajfel, H., \& Turner, J. C. (1979). An integrative theory of intergroup conflict. In W. G. Austin \& S. Worchel (Eds.), The social psychology of intergroup relations (pp. 33-47). Monterey, CA: Brooks/Cole. 
Ulriksen, S. (2002). Den norske forsvarstradisjonen - militcermakt eller folkeforsvar? [The Norwegian defense tradition - military power?]. Oslo: Pax Forlag A/S.

Van Boxmeer, L. E. L. M., Verwijs, C., de Bruin, R., \& Euwema, M. C. (2007, month). A direct measure of morale in the Netherlands' Armed Forces Morale Study:

Theoretical puzzle, empirical testing and validation. Paper presented at the Annual International Military Testing Association (IMTA) Congress, Gold Coast, Australia, october, 2007).

Van Boxmeer, L. E. L. M., Verwijs, C., Duel, J., \& Euwema, M. C. (September /October, 2008). Measuring morale and psychological distress of soldiers during modern military operations: Building a network of relationships among morale and psychological distress. Paper presented at the IMTA conference, Amsterdam.

Van Dick, R., Wagner, U., Stellmacher, O.C., \& Christ, O. (2005). To be(long) or not to be(long): Social identification in organizational contexts. Genetic, Social and General Psychology Monographs, 13, 189-218.

Vinokur, A. D., Pierce, P. F., Lewandowski-Romps, L., Hobfoll, S. E., \& Galea, S. (2011). Effects of war exposure on air force personnel's mental health, job burnout and other organizational related outcomes. Journal of Occupational Health Psychology, 16, 317. doi:10.1037/a0021617

Wagner, U., Stellmacher, J., Christ, O., \& Tissington, P. A. (2005). To Be(long) or Not to $\mathrm{Be}$ (long): Social Identification in Organizational Contexts. Genetic, Social, and General Psychology Monographs, 131(3), 189-218

Woodruff, T., Kelty, R., \& Segal, D.R. (2006). Propensity to serve and motivation to enlist among American combat soldiers. Armed Forces \& Society, 32, 353-366. Doi: $10.1177 / 0095327 X 05283040$

Wong, L., \& Johnson D.V. (2002). Serving the American people: A historical view of the Army profession. In D. M. Snider \& G. L. Watkins (Eds.), The future of the army profession (pp. 537-538). USA: McGraw-Hill. 